\title{
Assessing the Role of Microfinance on Women Empowerment: A case of PRIDE (T) -Shinyanga
}

\author{
Gwahula Raphael $(\mathrm{PhD})$ \\ Department of accounting and Finance, Open University of Tanzania, Tanzania \\ E-mail: gwahulagr@gmail.com
}

Geofrey Isaack Mrema

Ministry of Finance and Planning, Tanzania

Received: November 1, 2016 Accepted: December 1, 2016

doi:10.5296/ber.v7i2.10238ＵRL: https://doi.org/10.5296/ber.v7i2.10238

\begin{abstract}
The objective of the study was to assess the role of micro finance (PRIDE) on women empowerment in Shinyanga Municipality. The study tried to assess two specific objectives which were to assess the best way to be considered by pride to empower women and assess the relationship between the roles of micro finance on women empowerment. The study used a sample of 92 beneficiaries of microfinance services from micro finance institution, PRIDE (T). Microfinance services and entrepreneurial skills were independent variables and women empowerment was the dependent variable. The researcher used primary data collection tools such as interviews. The findings revealed that both microfinance services contribute 97 percent of women empowerment and entrepreneur skills also contribute 71.4 percent on women empowerment. Finding from the multiple linear regressions showed that reduction of harsh condition, increase of entrepreneur skills, saving, loan and reduction of interest rate were $0.327,0.316,0.274,0.370$, and 0.289 respectively. The model explained that there is direct relationship between women empowerment and the role of micro finance services as well as entrepreneur skills.
\end{abstract}

Keywords: Microfinance services, Interest rate, Harsh condition, Loan, Saving entrepreneurial skills, Investment and women, Empowerment, PRIDE (T)

\section{Introduction and Background}

Empowerment of women is a global challenge since traditionally women have been marginalized and subjected under the control of men. About 70 percent of world's poor are 
women, and about 60 percent of women in Tanzania live in absolute poverty (Khan and Noreen, 2012). URT, (2011) reports that women have no access to credit and other financial services as most of them are with and low business management skills. Furthermore, traditionally the position of women in Tanzania has been low compared to men; women were not expected to influence the decision-making processes from domestic level to the national level (URT, ibid). The author claims other related women challenges including: women subject to men who are considered as heads of family, women are legally illiteracy as there is discriminatory application of statutory laws, and inadequate legislative protective mechanism. Sigalla, (2007) emphasizes that like many societies in Africa, customary laws and practices remain discriminatory against women on issues of property inheritance particularly on land, as well as institutionalized violence against women. In the past, women in African societies were perceived as home creatures as they were segregated economically, socially, politically as well as culturally. They were more likely than men to be poor and illiterate. The author adds that women had relatively very little, in terms of property ownership, credit, training and employment; far less likely than men to be politically active, in decision making and more likely to be victims of domestic violence (Sigalla, ibid).

Though different challenges exist relating to women, the international measures and national measures have been taken. The 1990s witnessed a progressive awareness of the role of micro credit in eradication of poverty. Such awareness is shown in the resolution adopted by the United Nations in 1998, proclaiming the year 2005 as the "International Year of Microcredit". The declaration specifically mentions microcredit programmes to have "especially benefited women and have resulted in the achievement of their empowerment" (UN, 1999). Further, African governments including Tanzania made different efforts to formalize the women empowerment and empowerment procedures. However, when the term empowerment is used generally to mean raising up women's awareness for them to start to participate in various sectors namely economic, political, cultural and social activities However, the current study would restrict the above definition to financial empowerment for them to be actively engage in business in turn for their social and economic well being. In recent years, the president of United Republic of Tanzania, Jakaya Mrisho Kikwete established the empowerment fund popularly known as 'JK billions' hoping that it may reduce poverty. Microfinance services has been and increasingly become a popular intervention against poverty in developing countries, generally targeting poor women (Leach \& Sitaram, 2002).

While the international and national efforts such as Tanzanian government had been attempted to empower women, it is recognized that the role of microfinance in empowering women in turn for their family development should be emphasized. For example, Microfinance services are considered a key development tool, particularly for women (Guérin, 2006). It has been argued that not only do female borrowers have better repayment records (Sharma and Zeller, 1997), but return on investments seem to better reach all household members, particularly, in the context of improving children's health and facilitating their schooling (Pitt and Khandker, 1998). It has also been argued that microfinance services have had a positive impact by improving women's self-esteem as well as their families' status (Amin et al., 1998; Panjaitan et al., 1999).The question in mind is that does the effect of microfinance institution on women's 
empowerment with a positive effect? To respond to the question, different studies have reported a mixed of results; for instance, (Holvoet, 2005; Mayoux and Hartl, 2009;) (Mbololo, 2013; Nyabwala, 2010; Chirkos, 2013; Gogadi,2011). While some are supportive of microfinance's ability to induce a process of economic, social and political empowerment, others are more skeptical and even point to deterioration of women's overall wellbeing (Holvoet, 2005). Several studies show that access to microfinance contributes to women empowerment, particularly for women participants, and to overall poverty reduction at the village level. It also contributes to women's empowerment, including higher levels of mobility, political participation and decision-making. Microfinance has been seen as contributing not only to women empowerment on social sector and financial sustainability, but also to a series of 'virtuous spirals' of economic empowerment, increased well-being and political empowerment for women themselves, thereby addressing goals of gender equality and empowerment as it seen in Asian countries (Mayoux and Hartl, 2009). It is therefore the motive of the researcher in this study to assessing the role of microfinance on women empowerment: a case of PRIDE (T)-Shinyanga. Specifically, the study focused on two objectives namely: assessing the best way to be taken by PRIDE (T) to empower women and the second being assessing the relationship between the roles of micro finance on women empowerment.

\subsection{Background of the Studies on Women Empowerment}

Not surprisingly, empirical studies show that the role of MFIs to women empowerment share a mixed of results (Mbololo, 2013; Nyabwala, 2010; Chirkos, 2013; Gogadi, 2011). Other scholars concur that microfinance institution has brought little impact to women well being in general; for instance, Mbololo, (2013) who studied the role of MFIs on women empowerment on poverty reduction by employing qualitative and quantitative method with 385 respondents has been found that MFIs impacts lowly in poverty reduction to loans beneficiaries such as women due to low level of education they have. The author also found that $63 \%$ of women had lower level of education. The study recommendation given by the researcher was that MFIs staff should undergo training on how their finance can improve their services to customers, especially women; similarly, Nyabwala, (2010) whose study focused on how women can be empowered by employing a cross section survey method with 80 respondents and questionnaires, interviews, observation and documentary review had found the related findings. The author reports that most of SMEs financed by the MFIs were for individuals who were experiencing financial difficulties in getting capital to run their businesses. In addition, the majorities were not comfortable with the terms and conditions that had been put in place by the MFIs to access the loans which made them fail to return the loans given at a right time.

Contrary to the above observations, Chirkos, (2013) and Gogadi, (2011) findings contrast with the above authors; for instance, Chirkos who conducted a study in Ethiopia and ACSI as the case study with the focus to assess the impact of MFIs on the livelihood of the poor people, especially women found that MFIs have boosted loans lenders to some extent because majority of parents have sent their children to school, and improved payment of health services. The study employed both qualitative and quantitative approach from which 
questionnaires were used to collect information from 150 respondents. likewise the findings concurred with the study done by Gogadi, (2011) who found that services offered by PRIDE help to empower women economically; their training on entrepreneurship skills led to reduction of poverty and job creation which led to improving their standard of living. The study involved 100 respondents who were selected among member of staff and customers of PRIDE (T). The methodology used was descriptive in nature with questionnaires, interviews and observation as the tools to be administered to the respondents.

\section{Methodology}

\subsection{Population and Sampling Techniques}

The researchers employed probability to get samples of respondents, whereby under probability sampling, the simple random was used to obtain 92 sample of women food vendors at Kambarage ward. As the popularity of multiple linear regressions (MLR) has increased, the question of how large a sample is required to produce reliable results has become increasingly more important to address. "As with any statistical analysis that is computed using sample data, the size of the sample (n) in large part determines the value of the statistical results of a multiple regression analysis" (Gross, 1973: 17).

In this study the population of the study which used was 110 respondents. With regard to the sample size, the researcher applied a simplified formula provided by Yamane, (1967) to determine the minimum required sample size at $95 \%$ confidence level, degree of variability $=$ 0.5 and level of precision $(\mathrm{e})=0.05$

$$
\mathrm{n}:=\frac{N}{1+N e^{2}}
$$

Where $\mathrm{n}$ is sample size, $\mathrm{N}$ is the total number of study population, 110

Where e is the level of precision

$$
\begin{aligned}
& \mathrm{n}=110 /\left(1+110^{*} 0.05^{\wedge} 2\right) \\
& \mathrm{n}=86.3=87 \text { respondents }
\end{aligned}
$$

\subsection{Sample Size, Data Collection Method and Tools and Study Area}

A sample size of 92 respondents in Shinyanga Municipal was considered. This was done with the aim of ensuring accessibility, easy management and cost reduction on data collection by the researchers. In order to accomplish the objectives in this study and come up with reliable results we used both primary as well as secondary data. The primary data collection method that was used during the study include: interview and secondary data collection method that was used include documentation. The study used a set of predetermined and structured questions which were given to the beneficiaries to answer by the help of the researcher. 


\section{Finding and Discussion}

\subsection{Demographic Profile of Respondents}

The study used age because age has influence on the ability to work and ability to conduct business; it influences the ability to save and demand for bank services. The study showed the age of beneficiaries. The age was measured in years ranging from 18 - 25, 26 - 40 and above 40. The respondents with the age between 18 to 25 were 10 equivalents to 10.9 percent, the respondents with the age between 26 to 40 years were 51 equivalent to 55.4 percent, and those with the age above 40 years were 31 which is equivalent to 33.7 percent of the total. It can be seen from the study that most of women food vendors were young women as majority of women food vendor fall under age of 26 to 40 years.

The total number of respondents was 92. Marital status of respondents was categorized as married, not married, widowed and divorced. We were interested to know how marital status relates to women food vendor business. It was found that 53.3 percent were married, 17.4 percent were not married and the remaining 26.1 percent were widows and 3.3 percent were divorced; the majority of respondents were married.

The study was interested in the level of education of beneficiaries. Education was measured by the kind of education attained. Those who did not go to school were 7 , this was equivalent to 7.6 percent, those who attended primary school were 71 equivalents to 77.2 percent and lastly those who attended secondary school were 14, equivalent to 15.2 percent. Most of respondents were mainly in the class of those who had attended only primary school.

\subsection{Client Response on the Best Way to be considered by PRIDE to Empower Women}

Table 1. Factors to Empower Women

\begin{tabular}{|l|l|l|c|}
\hline \multicolumn{1}{|c|}{ Factors } & N & Mean & Std. Deviation \\
\hline Increase loan amount & 92 & 3.3261 & 1.46841 \\
\hline Reduce harsh condition & 92 & 2.2935 & 1.37112 \\
\hline Providing entrepreneur Skills/education & 92 & 2.2500 & 1.31454 \\
\hline Reduce interest rate & 92 & 2.4348 & 1.27791 \\
\hline Increase loan repayment period & 92 & 3.2065 & 1.58661 \\
\hline Valid N (list wise) & 92 & & \\
\hline
\end{tabular}

Source: Primary data

Table 1 shows the respondents altitudes concerning the best way to be considered to empower women. The variable was tested to show the best way which might be taken by PRIDE to empower women. On average the majority of the respondents interviewed strongly agreed with the factors above that contribute to the empowerment of women since there is little deviation and standard errors in their opinion. All factors have a mean of an average of 2.3 with standard deviation of an average of 1.3. Increase loan amount has average mean of 3.32 and 1.46 standard deviations, this shows that most of respondent are in neutral position or 
indifferent decision about this factor on whether it is the way to empower women or not. Reduction of harsh condition has an average mean of 2.29 and standard deviation of 1.37, provision of entrepreneur skills has an average mean of 2.25 and standard deviation of 1.31, reduce interest rate has an average mean of 2.43 and standard deviation of 1.27 and lastly increase loan repayment period shows that the average mean was 3.206 and standard deviation of 1.586 .

Generally the mostly and strongly factors which have been accepted by most of the respondents to be the best way to empower women were reduction in interest rate, reduction of harsh condition and provision of entrepreneur skills. These have become the key factors as most of respondent have strongly agreed with minimum variance among them. This has been obtained also by the research done by Kato and Kratzer (2013) in Tanzania, the researchers took three regions as a case study and they came up with the same factor as one of the best way to empower women economically.

\subsection{Experienced Women View's on the Best Way to Empower WFV}

Table 2. Experienced Women View's on the Best Way to Empower WFV

\begin{tabular}{|l|c|c|c|}
\hline & $\mathrm{N}$ & Mean & Std. Deviation \\
\hline Increase loan amount & 23 & 3.6522 & 1.46501 \\
\hline Reduce harsh condition /terms of loan & 23 & 2.5652 & 1.40861 \\
\hline Providing entrepreneur skills/education & 23 & 2.2174 & 1.44463 \\
\hline Reduce interest rate & 23 & 2.3913 & 1.11759 \\
\hline Increase loan repayment period & 23 & 3.4348 & 1.61881 \\
\hline Valid N (list wise) & 23 & & \\
\hline
\end{tabular}

Sources: primary data

Table 2 shows the respondents who have experience in working as mama lishe for more than 10 years. They believed that reduction of interest rate, provision of entrepreneur skill, and reduction of harsh condition are the most factors which empower women economically, this is exemplified by the three factors at the mean value of 2.39, 2.21 and 2.56 respectively at the slight deviation of $1.11,1.44$ and 1.41 respectively, when compared with other factors. Twenty three beneficiaries with experience of more than 10 years were interviewed. while the general result show that the mean for that factor was 2.43 at the standard deviation of 1.27 , factor of reduction of interest rate had a mean value of 2.39 at 1.11 standard deviations; while the general results had a mean of 2.25 at the standard deviation of 1.31 , the provision of entrepreneur skills had a mean value of 2.21 at standard deviation of 1.44; while general result had a mean of 2.29 at standard deviation of 1.37 , reduction of harsh condition has a mean of 2.56 at a standard deviation of 1.41; while the general results had a mean of 3.32 at standard deviation of 1.46; increase loan amount has a mean of 3.65 at the standard deviation of 1.46; while the general result has a mean of 3.206 with standard deviation of 1.586; increase loan repayment period has a mean of 3.43 at the standard deviation of 1.62 . 


\section{Al Macrothink}

Business and Economic Research ISSN 2162-4860 2017, Vol. 7, No. 2

The finding from experienced women concluded that the best way to be considered to empower women was reduction of interest rate, reduction of harsh condition or term of the loan to be friendlier as well as provision of entrepreneur skills.

The findings above show that both general result from all respondent and the experienced women who have worked for more than 10 years have confirmed that the reduction in interest rate, provision of entrepreneur skill and reduction of harsh condition are the only factors which can empower women since they have small mean with small deviation among them while the rest are not.

\begin{tabular}{|l|c|c|c|c|}
\hline & \multicolumn{2}{|c|}{ Above 10 years (Experienced) } & \multicolumn{2}{c|}{ All period (general result) } \\
\hline & Mean & Standard Deviation & Mean & Standard Deviation \\
\hline Increase loan amount & 3.65 & 1.46 & 3.32 & 1.46 \\
\hline $\begin{array}{l}\text { Reduce harsh } \\
\text { condition /terms of loan }\end{array}$ & 2.56 & 1.41 & 2.29 & 1.37 \\
\hline $\begin{array}{l}\text { Providing entrepreneur } \\
\text { skills/education }\end{array}$ & 2.21 & 1.44 & 2.25 & 1.31 \\
\hline Reduce interest rate & 2.39 & 1.11 & 2.43 & 1.27 \\
\hline $\begin{array}{l}\text { Increase loan repayment } \\
\text { period }\end{array}$ & 3.43 & 1.61 & 3.21 & 1.58 \\
\hline
\end{tabular}

Source: primary data

3.4 Respondents' Views who have Applied Loan as Individual towards the Best Way to be Taken by PRIDE to Empower Women

Table 3. Respondents' Views of those who have Applied Loan as Individual

\begin{tabular}{|l|c|c|c|}
\hline & N & Mean & Std. Deviation \\
\hline Increase loan amount & 33 & 3.3636 & 1.47517 \\
\hline Reduce harsh condition /terms of loan & 33 & 2.3636 & 1.45384 \\
\hline Providing entrepreneur skills/education & 33 & 2.1515 & 1.37207 \\
\hline Reduce interest rate & 33 & 2.4848 & 1.25303 \\
\hline Increase loan repayment period & 33 & 3.0909 & 1.56851 \\
\hline Valid N (list wise) & 33 & & \\
\hline
\end{tabular}

Source: primary data

Table 3 shows the response of respondents who have applied loan as individual towards the best ways to be considered by PRIDE to empower women. The researcher tested 33 respondents who have applied as individual. The findings show the factors that all respondents have strongly agreed with, they include reduction of interest rate, provision of entrepreneur skills and reduction of hash condition as the best ways to empower women as they have a mean of 2.48, 2.15 and 2.36 at the standard deviation of $1.25,1.37$ and 1.45 respectively. The least factor was to increase the loan repayment period and increase loan 
amount as they found with higher mean value of 3.09 and 3.36 at standard deviation of 1.56 and 1.47 .

In conclusion to the factors to be considered as the best way to empower women, from various groups of respondents which have tested are reduction of interest, reduction of harsh condition and provision of entrepreneur skills or education.

\subsection{Assessment of the Impact of Micro Finance Services on WFV}

Table 4. Assessment of the impact of micro finance services on WFV

\begin{tabular}{|l|c|c|c|}
\hline & N & Mean & Std. Deviation \\
\hline Control over saving account & 92 & 2.2935 & .83255 \\
\hline Greater role in decision making & 92 & 2.0543 & 1.06249 \\
\hline Greater self-efficacy & 92 & 2.3478 & 1.20835 \\
\hline Self esteem & 92 & 2.4239 & 1.21559 \\
\hline Greater freedom of mobility & 92 & 2.0109 & 1.05346 \\
\hline Recognition in societies & 92 & 2.1304 & .99689 \\
\hline to meets its basic needs & 92 & 2.0978 & 1.03838 \\
\hline Financing education & 92 & 2.0978 & 1.03838 \\
\hline Home improvements & 92 & 2.0870 & 1.01258 \\
\hline Starting a new business & 92 & 2.1630 & 1.03007 \\
\hline Expanding the existing business & 92 & 2.1304 & .98580 \\
\hline Acquisition of assets & 92 & 2.2935 & 1.00042 \\
\hline Valid N (list wise) & 92 & & \\
\hline
\end{tabular}

Sources: primary data

Table 4 shows the altitude towards the relationship between the role of microfinance and women empowerment. The findings show that the respondents have strongly agreed with the factors above with an average mean range from 2.0 to 2.34 with standard deviation which range from 0.83 to 1.21 . This showed that most of them had strongly agreed with the impacts of the micro finance. Acquisition of asset has mean value of 2.29 with little deviation of 1.00; home improvement has also a mean value of 2.09 at little deviation of 1.01 and most of respondent have strongly agreed. Financing education is one of an impact from the role of women empowerment since it has a mean value of 2.09 at standard deviation of 1.03; to meet basic needs has a mean value of 2.09 with standard deviation of 1.03 ; recognition in the societies also has a mean value of 2.13 at standard deviation of 0.99 - this also show that most respondents have strongly agreed with the factor. In case of the role in decision making, most of respondent have agreed with the role of decision making as it found with the mean value of 2.05 at standard deviation of 1.06. The rest of the factors were found with slightly different in terms of means and standard deviation. 
3.6 Assessment on the Respondents View on the Loan and Saving Utilization

Table 5. Assessment on the Respondents View on the Loan and Saving Utilization

\begin{tabular}{|l|l|l|l|}
\hline & $\mathrm{N}$ & Mean & Std. Deviation \\
\hline increased income & 92 & 2.6848 & 1.32540 \\
\hline improved social services & 92 & 2.7935 & 1.41839 \\
\hline self-employment & 92 & 2.7826 & 1.35733 \\
\hline self-independent & 92 & 2.7174 & 1.35327 \\
\hline Valid N (list wise) & 92 & & \\
\hline
\end{tabular}

Source: primary data

Table 3.5 shows the attitude of respondents towards loan and saving utilization. The researcher was trying to find out the benefit obtained through saving and loan utilization among the respondents. The result shows that the respondents have accepted and agree on the factors or impact of loan and saving utilization. They agree that loan and saving utilization have helped them to increase the income and being self-independent. This is true because increased income has a mean of 2.68 with standard deviation of 1.33 and being self-independent has a mean of 2.71 with standard deviation of 1.35 . The other factors are improved social service and self-employment; have mean of 2.79 and 2.78 with the standard deviation of 1.41 and 135 respectively.

\subsection{Correlation between Role of PRIDEs and Women Empowerment}

Correlation is a term that refers to the strength of a relationship between two variables. Correlation coefficients -1.00 represent a perfect negative correlation while a value of +1.00 represents a perfect positive correlation. A value of 0.00 means no relationship between the variables being tested. Appendix 3 describes the relationship between the role of micro finance and women empowerment Pearson correlation was used given a two tail test (2-tailed). The results summarized in a Pearson correlation matrix indicate that the correlation coefficient between role of micro finance and women empowerment is positive 0.628 as an average. The probability value ( $\mathrm{P}$-value) is 0.000 less than the significance level which is 0.05. The role of micro finance/services and women empowerment moves together in the same direction.

\subsection{Testing the Assumptions of Multiple Linear Regression Model}

\subsubsection{Mult-collinearity test on Independent Variables}

Before running regression, the test of multi-collinearity between independent variables was done. Presence of multicollinearity inflates the variance of the parameter estimates making them individually statistically insignificant even though the overall model may be significant. In addition multi-collinearity causes problems in estimation of the coefficients of independent variables and their interpretation. The tolerance rate and Variance Inflating Factors (VIF) were used to detect multi-collinearity between explanatory variables as follows: 
Table 6. Results of multi-collinearity test between independent variables

\begin{tabular}{|c|c|c|}
\hline \multicolumn{3}{|l|}{ Coefficients $^{\mathrm{a}}$} \\
\hline \multirow[t]{2}{*}{ Model } & \multicolumn{2}{|c|}{ Collinearity Statistics } \\
\hline & Tolerance & VIF \\
\hline 1) Harsh condition & .479 & 2.087 \\
\hline entrepreneur skill & .408 & 2.452 \\
\hline saving & .582 & 1.719 \\
\hline loan & .567 & 1.762 \\
\hline interest rate & .401 & 2.493 \\
\hline
\end{tabular}

a. Dependent Variable: WE

Table 6 indicates that the tolerance is greater than $0.1(10 \%)$ and the variance inflating factor (VIF) does not exceed 5 to 10 . The study concluded that there is no problem of multi-collinearity among explanatory variables. Therefore, the associated regression coefficients are clearly estimated and reliable.

\subsubsection{Checking Linearity between Dependent and Independent Variables}

Appendix 1 shows the analysis to test the linear relationship between variables. To achieve this objective the researcher used correlation matrix to establish whether the included variables were linear or not. Relationship is linear if the difference between correlation coefficient and non-linear correlation is small. The probability associated with correlation coefficient between reduction of harsh condition and women empowerment is 0.000 while the correlation coefficient is 0.742 larger than the probability. This implies that the relationship between women empowerment and reduction of harsh condition is linear. The same applies to the relationship between women empowerment and provisional of entrepreneur skills whereby the correlation coefficient is 0.714 while the probability value is 0.000 indicating that there is linear relationship between the two variables in the model. Also there is a positive relationship between saving and loan with the correlation $0.457,0.537$ respectively with women empowerment.

The correlation coefficient between women empowerment and reduction of interest rate is 0.689 while the probability value is 0.000 indicating also that the two variables have a positive linear relationship.

\subsubsection{Test of Autocorrelation Assumption (Durbin Watson Test)}

Table 7. Test of autocorrelation assumption

\begin{tabular}{|l|l|l|l|l|l|}
\hline \multicolumn{5}{|l|}{ Model Summary } \\
\hline Model & R & R Square & Adjusted R Square & Std. Error of the Estimate & Durbin-Watson \\
\hline 1 & $.995^{\mathrm{a}}$ & .991 & .990 & .40962 & 2.123 \\
\hline
\end{tabular}

a. Predictors: (Constant), interest rate, loan, saving, harsh condition, entrepreneur skill 
b. Dependent Variable: WE

Table 7 illustrates the results of the test of independence of observations. The test was done using Durbin Watson test. Multiple linear regressions assume that the errors are independent and there is no serial correlation. Errors are residuals or differences between the actual score for a case and the score estimated using the regression equation. No serial correlation implies that the size of the residual for one case has no impact on the size of the residual for the next case. Durbin Watson statistic is used to test the presence of serial correlation among the residuals. The value of the Durbin Watson statistic ranges from 0 to 4 as a general rule of thumb, the residuals are not correlated if the Durbin Watson statistic is approximately 2 and an acceptable range is 1.5 to 2.50 .

The results in Table 3.7 show that the Durbin Watson statistic is 2.123 which fall within the acceptable range. It implies that there is no serial correlation of errors and therefore the model was correctly specified.

\subsubsection{Test of Normality}

Table 8. Test of Normality

\begin{tabular}{|l|l|l|l|l|l|l|}
\hline Tests of Normality & \multicolumn{3}{l}{ Kolmogorov-Smirnova } & \multicolumn{3}{l|}{ Shapiro-Wilk } \\
\hline & Statis ic & Df & Sig. & Statistic & df & Sig. \\
\hline Factors & .280 & 92 & .000 & .807 & 92 & .000 \\
\hline Harsh condition & .271 & 92 & .000 & .817 & 92 & .000 \\
\hline Entrepreneur skill & .296 & 92 & .000 & .839 & 92 & .000 \\
\hline Interest rate & .321 & 92 & .000 & .824 & 92 & .000 \\
\hline Saving & .326 & 92 & .000 & .817 & 92 & .000 \\
\hline Loan & .176 & 92 & .000 & .927 & 92 & .000 \\
\hline WE & & & & & & \\
\hline a. Lilliefors Significance Correction & & & & & \\
\hline
\end{tabular}

Table 8 shows that the P-value of reduction of harsh condition is 0.000 and provision of entrepreneurs kill is 0.000 and all other factors has 0.000 probability using Shapiro-Wilk test of normality. This probability values is greater than the 0.01 level of significance indicating that the two variables are normally distributed. However, the P-value of reduction of interest rate at 0.000 is less that the level of significance at 0.01 . The results show that the two variables are not normally distributed.

According to Ghasemi and Zahedias (2012) with large sample size which is greater than 30 or 40 like the sample used in this study, violation of normality assumption should not cause major problems meaning that sampling distribution tend to be normal regardless of the shape of data.

\subsubsection{Test of Homoscedasticity Assumption}

Heteroscedasticity means presence of error of variance in the linear regression model which 


\section{Il Macrothink}

Business and Economic Research

ISSN 2162-4860

2017, Vol. 7, No. 2

is a violation against homoscedasticity variance assumption. Gujarat and Porter (2010) state that heteroscedasticity can be diagnosed by using White Test. According to them, White Test can be done by comparing the value of calculated and observed Chi-square values by using the formula: $\chi^{2}=N \times R^{2}$ whereby $\chi^{2}=$ is the calculated Chi-square, $\mathrm{N}=$ is the number of observation and $\mathrm{R}^{2}=\mathrm{R}$-Square or coefficient of determination. The rule of thumb is: When Chi-square calculated is less than Chi-square observed there is no heteroscedasticity problem in the model. From the data analysis (Table3.7) $\mathrm{R}^{2}=0.991$ and $\mathrm{N}=92$, therefore calculated $\chi^{2}=0.991 \times 92=91.17$ while the Chi-square observed at 0.05 level of significance and $\mathrm{N}=$ 90 is 96.205 The result indicate that calculated Chi-square is less that observed Chi-square which imply that the model does not exhibit heteroscedasticity problem

\subsection{Results of Regression of Independent Variables against Dependent Variable}

Women empowerment was regressed against reduction of interest rate, reduction of harsh condition, raving, loan and entrepreneurial skills to estimate the model for explaining the extend microfinance services and entrepreneurial skills have contributed in women empowerment was the dependent variable and microfinance services and entrepreneurial skills were explanatory variables.

To achieve this, multiple linear regressions were done on microfinance services and entrepreneurial skills as explanatory variables of women empowerment. The components of microfinance role and service include interest rate and harsh condition, saving loan and those of entrepreneurial skills.

The model was specifies as follows:

$$
W E=\beta_{0}+\beta_{1} L+\beta_{2} S+\beta_{3} I+\beta_{4} E S+\beta_{5} \mathrm{HC}+\mu
$$

Whereby $\beta_{0}$ is the constant term of the model, $\beta_{1}$ to $\beta_{5}$ are coefficients of independent variables and $\mu$ is the error term. The results are presented in Tables 3.9a 3.9b, and 3.9c below:

Table 9. Results of Regression

Table 9a

\begin{tabular}{|l|l|l|l|l|l|}
\hline \multicolumn{4}{|l|}{ Model Summary } \\
\hline Model & $\mathrm{R}$ & R Square & Adjusted R Square & Std. Error of the Estimate & Durbin-Watson \\
\hline 1 & $.995^{\mathrm{a}}$ & .991 & .990 & .40962 & 2.123 \\
\hline \multicolumn{7}{|l|}{ a. Predictors: (Constant), interest rate, loan, saving, harsh condition, entrepreneur skill } \\
\hline
\end{tabular}


Table $9 \mathrm{~b}$

\begin{tabular}{|l|l|l|l|l|l|l|}
\hline \multicolumn{7}{|l|}{ ANOVA $^{\mathrm{b}}$} \\
\hline \multicolumn{2}{|l|}{ Model } & Sum of Squares & df & Mean Square & F & Sig. \\
\hline \multirow{2}{*}{1} & Regression & 1551.874 & 5 & 310.375 & $1.850 \mathrm{E} 3$ & $.000^{\mathrm{a}}$ \\
\cline { 2 - 8 } & Residual & 14.430 & 86 & .168 & & \\
\cline { 2 - 8 } & Total & 1566.304 & 91 & & & \\
\hline
\end{tabular}

a. Predictors: (Constant), interest rate, loan, saving, harsh condition, entrepreneur skill

b. Dependent Variable: WE

Table 9c

\begin{tabular}{|l|l|l|l|l|l|l|}
\hline \multicolumn{2}{|l|}{ Coefficients $^{\mathrm{a}}$} & \multicolumn{2}{l|}{ Unstandardized Coefficients } & Standardized Coefficients & & \\
\cline { 2 - 7 } Model & $\mathrm{B}$ & Std. Error & Beta & t & Sig. \\
\hline 1 (Constant) & .216 & .139 & & 1.546 & .126 \\
\hline harsh condition & .988 & .045 & .327 & 21.842 & .000 \\
\hline entrepreneur skill & .997 & .051 & .316 & 19.487 & .000 \\
\hline Saving & .848 & .042 & .274 & 20.170 & .000 \\
\hline Loan & 1.149 & .043 & .370 & 26.923 & .000 \\
\hline Interest rate & .938 & .053 & .289 & 17.682 & .000 \\
\hline a. Dependent Variable: WE & & & & \\
\hline
\end{tabular}

$$
W E=0.216+0.327 h c+0.316 e s+0.274 s+0.370 l+0.289 i+\mu
$$

\section{Discussion of Findings/Results}

\subsection{Best Way to be considered to Empower Women}

It is true that the role of micro finance service has an impact on women empowerment. To prove that we present the findings which have portrayed that the majority of respondents agreed that reduction of harsh condition from microfinance, provision of entrepreneur skills and reduction of interest rate contribute to women empowerment. The respondents commented that those three factors above contributed to increased income, acquisition of asset, home improvement and recognition in the society. Moreover, other area of recognition include: financing education for their children, meeting basic needs, increasing the role to decision making in the family as well as generation of self employment. These findings are in agreement with the studies done by Gogadi, (2011) who commented that PRIDE helps to empower women economically by leading to higher level of entrepreneurship skills so as to reduce poverty. However, the research done by Temba, (2014), using CRDB as the case study aimed to find out how MFIs can accelerate women empowerment. The author also reported that poor entrepreneurship skills are among of the challenges that make women poor 
economically.

The finding has shown that when the microfinance institution performs its role effectively and efficiently will result into women empowerment. Those roles of micro finance helped to increase income by mean of 2.54 at the standard deviation of 1.18; self independent had a mean value of 2.55 at standard deviation of 1.17.It showed that the role of micro finance also help women to be recognized in the society, it also helped women in decision making and improvement of home affair- such findings were exemplified at the mean value of 2.13, 2.05, 2.087 respectively with standard deviation of $0.99,1.062,1.01$ respectively; generating activities like financing education and acquisition of assets as indicated by mean score of $2.09,2.29$ at the standard deviation of 1.03, 1.00 respectively. This implies that micro finance have a strong contribution in women empowerment if they are used to finance income generating activities.

The coefficient of provision of entrepreneur skills in a regression model when tested against women empowerment was positive 0.316 which implies that they contribute positively in women empowerment. Any increase in provision of entrepreneur skills provided by PRIDE results into women empowerment by 0.316 units. Microfinance is a good strategy for women empowerment but there is a need to provide much training on entrepreneur skills/business skills since the training help them to be aware of the business that they are going to conduct. The findings on reduction of harsh condition revealed that majority PRIDE's beneficiaries have agreed about the impact of reduction of harsh condition in women empowerment. Coefficient of reduction harsh condition in an estimated regression model was positive related by 0.327 implying that any change in reduction of harsh condition leads to increased in women empowerment by 0.327 . The results of regression analysis indicate that reduction of interest rate and women empowerment are positively related. The coefficient of interest in an estimated regression model was positive 0.289 implying one unit increase in savings leads to 0.289 units in women empowerment. This finding is supported by the research done by Nyabwala (2010) at Maseno University (Kisumu) aiming to look on how women can be empowered. The researcher employed cross section survey method with 92 respondents whereby questionnaires, interviews, observation and documentary review were used as the tools. The findings showed that most of SMEs financed by the MFIs were for individuals who were experiencing financial difficulties in getting capital to run their business. But most of them were not comfortable with the terms and conditions that have been put in place by the MFIs to access the loans; this made them to fail to return loans given at a right time.

The finding on micro finance saving and loan has shown that it contributes to women empowerment since it helps to finance some of investment like financing education, home improvement, acquisition of asset and others. Saving and loan hada positive coefficient of 0.274 and 0.370 respectively, this implied that one unit increase in savings leads to 0.274 and 0.370 units in women empowerment. The result was supported by a research done by Chirkos (2013) in Ethiopia by taking ACSI as the case study, the findings showed that MFIs have boosted loans lenders to some extent because few parents have sent their children to school and improved payment of medicals. 
The findings in this study indicate that microfinance service have a strong contribution in women empowerment, evidenced by increased income, improved social services like education and health as well as creation of self employment. This is in agreement with literature review by Kato and Kratzer (2013) who conclude that women members of MFIs have more control over savings and income generated from the business, greater role in decision-making, greater self-efficacy and self-esteem, greater freedom of mobility and increased activities outside home.

\subsection{Relationship between the Micro finance and Women Empowerment}

The study established a significant relationship between the role of micro finance and women empowerment. The findings imply that when PRIDE's service beneficiaries forgo current consumption for an increased future level of consumption, the resulting effect will be women empowerment. Appendix 3 shows a correlation matrix between the role of micro finance in form of reduction of harsh condition, reduction of interest rate, provision of entrepreneur skill, saving and loan and women empowerment. In correlation analysis, the purpose is to measure the closeness of linear relationship between the role of microfinance and women empowerment. In this study, the role of micro finance was the bridge for microfinance services and entrepreneurial skills to realize women empowerment. The correlation coefficient indicates how closely the data fit linear pattern.

The correlation coefficient $(r)$ between the two variables is positive 0.628 indicating that an increase of the role of micro finance corresponds to an increase in women empowerment. The positive sign of the correlation coefficient means that the variables move together in the same direction. On the other hand, majority of respondents who were asked to comment on the relationship or impact of the role of microfinance services and women empowerment said there is a significant relationship between those variables. Therefore, clients of PRIDE's services could empower themselves by opting to use the loans to finance investment projects.

\section{Conclusions}

The study tried to assess two objectives; one being assessing the best way to be taken by PRIDE (T) to empower women and the second being assessing the relationship between the roles of micro finance on women empowerment.

It has been established that the role of micro finance inform of provision of entrepreneur skills, reduction of harsh condition and reduction of interest rate, saving, loan have brought significance positive contribution in women empowerment. PRIDE's microfinance services explain women empowerment by 99 percent. In addition, the beneficiaries interviewed commented that the role of microfinance services and entrepreneur skills have significantly empowered women through increased income, improved social services and creation of self employment. Therefore, PRIDE's microfinance services are key determinants of women empowerment.

The findings revealed that PRIDE has been providing entrepreneurial skills although at a very minimal as confirmed by the clients interviewed. The training concentrated on familiarizing the beneficiaries with terms and conditions of loans and savings instead of providing skills 
which will enable clients to optimize the use of microfinance services. The beneficiaries interviewed explained that entrepreneurial skills are the corner stone for any successful investments and women empowerment but they confirmed that PRIDE are not doing enough to empower them in business skills. Loans and savings become effective if the beneficiaries have the necessary financial skills

The findings further reveal that the role of micro finance (services) is positively correlated to women empowerment. Beneficiaries who opted to invest their loans in income generating activities like acquisition of asset, finance education, home improvement and recognition in society have experienced women empowerment as a result of increase in income and improved social services.

\subsection{Policy Recommendations}

\subsubsection{The Study Recommends as Follows}

PRIDE (T) should start providing credit management training and entrepreneur skills to more women before giving the loan in order to help them to conduct business effectively and be able to repay the loans given on time and thus help to empower women economically.

The government should start supporting MFIs which deal with women because in doing so MFIs such as PRIDE (T) will be able to assist, develop, and empower more women economically in the process.

PRIDE (T) and other MFIs should conduct awareness campaign which will help women particularly food vendors to become more successfully and in the process encourage more people to become entrepreneur and thus empower women economically.

The staff of PRIDE (T) and other MFIs should try to understand and appreciate the nature of business to which they advance loan because business like the mama lishe involves perishable goods.

With regard to PRIDE's loan utilization, it was found that beneficiaries would like to undertake large scale investments like home improvements but the loans provided are inadequate, PRIDE should find other sources of financing that will enable to provide loans according to the needs of the beneficiaries. This can involve undertaking reinvestment strategies like investing in shares and bonds to earn dividends and capital gains.

It was found that PRIDE concentrates more on provision of loans and saving mobilization and little attention on provision of beneficiaries' business skills. Based on these findings, it is recommended that there should be a simultaneous provision of microfinance services in the form of loans and savings mobilization and entrepreneurial skills because they complement each other for effective poverty reduction.

It was found that PRIDE charge higher interest rate to beneficiaries; which put the beneficiaries in hard life after getting the loan due to higher interest rate. The researcher recommends that PRIDE and other MFIs should reduce the interest to be at a reasonable and affordable rate to enable beneficiaries to achieve their goals of improving economically. This 
will be done simultaneously with the government support to MFIs.

\section{References}

Ghasemi, A., \& Zahediasl, S. (2012). Normality tests for statistical analysis: a guide for non-statisticians. International journal of endocrinology and metabolism, 10(2), 486-489. https://doi.org/10.5812/ijem.3505

Gross, A. L. (1973). How large should sample size be in a regression analysis?. In Proceedings of the Annual Convention of the American Psychological Association. American Psychological Association.

Guérin, I., Kumar, S., \& Agier, I. (2013). Women's empowerment: Power to act or power over other women? Lessons from Indian microfinance. Oxford Development Studies, 41(sup1), S76-S94. https://doi.org/10.1080/13600818.2013.781147

Gujarat, D. N and Porter, C. P. (2010). Basic Econometrics. (5 ${ }^{\text {th }}$ Ed.). McGraw-Hill Company and China Renmin University Base.

Hirschland, M. (Ed.). (2005). Savings services for the poor: an operational guide (159-191). Bloomfield: Kumarian Press.

Holvoet, N. (2005). The impact of microfinance on decision-making agency: evidence from South India. Development and Change, 36(1), 75-102.

https://doi.org/10.1111/j.0012-155X.2005.00403.x

Kato, M. P., \& Kratzer, J. (2013). Empowering women through microfinance: Evidence from Tanzania. ACRN Journal of Entrepreneurship Perspectives, 2(1), 31-59

Khan, R. E. A., \& Noreen, S. (2012). Microfinance and women empowerment: A case study of District Bahawalpur (Pakistan). African Journal of Business Management, 6(12), 4514-4521. https://doi.org/10.5897/AJBM11.2407

Kothari, C. R. (2004). Research Methodology: Methods and Techniques, New Age, International Ltd, India Institute of Management, New Delhi: India.

Kwai, M. D., \& Urassa, J. K. (2015). The contribution of savings and credit cooperative societies to income poverty reduction: A case study of Mbozi District, Tanzania. Journal of African Studies and Development, 7(4), 99-111.

Leach, F., \& Sitaram, S. (2002). Microfinance and women's empowerment: A lesson from India. Development in Practice, 12(5), 575-588.

https://doi.org/10.1080/0961452022000017597

Lyngdoh, B. F., \& Pati, A. P. (2010). Microfinance Intervention and Socio-Economic Transformation: An Application of Propensity Score Matching and Difference-in-Difference Technique. Available at SSRN 1630268. https://doi.org/10.2139/ssrn.1630268

Makombe, I. A. M., Temba, E. I., \& Kihombo, A. R. M. (1999). Credit schemes and women's empowerment for poverty alleviation: the case of Tanga Region, Tanzania (No. 99). Research 
on Poverty Alleviation

Panjaitan-Drioadisuryo, R. D., \& Cloud, K. (1999). Gender, self-employment and microcredit programs an Indonesian case study. The Quarterly Review of Economics and Finance, 39(5), 769-779. https://doi.org/10.1016/S1062-9769(99)00028-9

Pitt, M. M., \& Khandker, S. R. (1998). The Impact of Group-Based Credit Programs on Poor Households in Bangladesh: Does the Gender of Participants Matter?. Journal of political economy, 106(5), 958-996. https://doi.org/10.1086/250037

Sharma, M., \& Zeller, M. (1997). Repayment performance in group-based credit programs in Bangladesh: An empirical analysis. World development, 25(10), 1731-1742.

https://doi.org/10.1016/S0305-750X(97)00063-6

Sigalla, R. (2007). A Study of Women's Lives, Self-Employment and Education in Tanzania, Open University of Tanzania, Dar es Salaam: Tanzania.

UN (1999). Progress of the World's Women., New York: USA

United Republic of Tanzania (1998). Poverty Reduction Strategic Paper, Dar es Salaam: Ministry of finance.

Yamane, T. (1967). Comprehensive Research Methodology, Int. publisher 886

Appendix 1. Regression of microfinance services/roles against women empowerment

\begin{tabular}{|l|c|r|r|r|}
\hline \multicolumn{3}{|l|}{ Appendix 1a: } & \multicolumn{3}{c|}{ Model Summary $^{\text {b }}$} \\
\hline Model & R & R Square & Adjusted R Square & Std. Error of the Estimate \\
\hline 1 & $.975^{\mathrm{a}}$ & .950 & .948 & .94775 \\
\hline a. Predictors: (Constant), loan, harsh condition, saving, interest rate \\
\hline \multicolumn{3}{|l|}{ b. Dependent Variable: WE } \\
\hline
\end{tabular}

\begin{tabular}{|c|c|c|c|c|c|}
\hline \multicolumn{3}{|l|}{ Appendix 1b } & \multicolumn{3}{|c|}{ ANOVA $^{\mathrm{b}}$} \\
\hline Model & Sum of Squares & $\mathrm{df}$ & Mean Square & $\mathrm{F}$ & Sig. \\
\hline 1 Regression & 1488.158 & 4 & 372.040 & 414.191 & $.000^{\mathrm{a}}$ \\
\hline Residual & 78.146 & 87 & .898 & & \\
\hline Total & 1566.304 & 91 & & & \\
\hline \multicolumn{5}{|c|}{ a. Predictors: (Constant), loan, harsh condition, saving, interest rate } & \\
\hline \multicolumn{2}{|c|}{ b. Dependent Variable: WE } & & & & \\
\hline
\end{tabular}




\begin{tabular}{|c|c|c|c|c|c|}
\hline \multicolumn{2}{|l|}{ Appendix 1c } & \multicolumn{4}{|c|}{ Coefficients $^{\mathrm{a}}$} \\
\hline \multirow[b]{2}{*}{ Model } & \multicolumn{2}{|c|}{ Unstandardized Coefficients } & \multirow{2}{*}{$\begin{array}{c}\text { Standardized Coefficients } \\
\text { Beta }\end{array}$} & \multirow[b]{2}{*}{$\mathrm{t}$} & \multirow[b]{2}{*}{ Sig. } \\
\hline & $\mathrm{B}$ & Std. Error & & & \\
\hline 1 (Constant) & .507 & .321 & & 1.579 & .118 \\
\hline Harsh condition & 1.290 & .098 & .426 & 13.119 & .000 \\
\hline Interest rate & 1.474 & .105 & .454 & 14.045 & .000 \\
\hline saving & .847 & .097 & .274 & 8.715 & .000 \\
\hline loan & 1.133 & .099 & .365 & 11.471 & .000 \\
\hline Dependent Var & ole: WE & & & & \\
\hline
\end{tabular}

Appendix 2. Regression of entrepreneur skill against women empowerment

\begin{tabular}{|l|c|r|r|r|}
\hline \multicolumn{3}{|l|}{ Appendix 2a } \\
\hline Model & R & R Square & Adjusted R Square & Std. Error of the Estimate \\
\hline 1 & $.714^{\mathrm{a}}$ & .510 & .505 & 2.91953 \\
\hline \multicolumn{3}{|l|}{ a. Predictors: (Constant), entrepreneur skill } \\
\hline
\end{tabular}

\begin{tabular}{|c|c|c|c|c|c|}
\hline \multicolumn{2}{|l|}{ Appendix 2b } & \multicolumn{4}{|c|}{ ANOVA $^{\mathrm{b}}$} \\
\hline Model & Sum of Squares & df & Mean Square & $\mathrm{F}$ & Sig. \\
\hline 1 Regression & 799.175 & 1 & 799.175 & 93.760 & $.000^{\mathrm{a}}$ \\
\hline Residual & 767.129 & 90 & 8.524 & & \\
\hline Total & 1566.304 & 91 & & & \\
\hline \multicolumn{3}{|c|}{ a. Predictors: (Constant), entrepreneur skill } & & & \\
\hline \multicolumn{2}{|c|}{ b. Dependent Variable: WE } & & & & \\
\hline
\end{tabular}

\begin{tabular}{|c|c|c|c|c|c|}
\hline \multirow[t]{2}{*}{ Appendix 2b } & \multicolumn{5}{|c|}{ Coefficients $^{\mathrm{a}}$} \\
\hline & \multicolumn{2}{|c|}{ Unstandardized Coefficients } & \multirow{2}{*}{$\begin{array}{c}\text { Standardized Coefficients } \\
\text { Beta }\end{array}$} & \multirow[b]{2}{*}{$\mathrm{t}$} & \multirow[b]{2}{*}{ Sig. } \\
\hline Model & $\mathrm{B}$ & Std. Error & & & \\
\hline 1 (Constant) & 7.341 & .606 & & 12.116 & .000 \\
\hline entrepreneur skill & 2.254 & .233 & .714 & 9.683 & .000 \\
\hline a. Dependent Variable: & WE & & & & \\
\hline
\end{tabular}




\begin{tabular}{|c|c|c|c|c|c|c|c|}
\hline \multirow[t]{2}{*}{ Appendix : 3} & \multicolumn{7}{|c|}{ Correlations } \\
\hline & & $\begin{array}{c}\text { Harsh } \\
\text { condition }\end{array}$ & $\begin{array}{l}\text { entrepreneur } \\
\text { skill }\end{array}$ & $\begin{array}{l}\text { Interest } \\
\text { rate }\end{array}$ & saving & loan & WE \\
\hline \multirow[t]{3}{*}{$\begin{array}{l}\text { Harsh } \\
\text { condition }\end{array}$} & $\begin{array}{l}\text { Pearson } \\
\text { Correlation }\end{array}$ & 1 & $.660^{* *}$ & $.660^{* *}$ & -.038 & .071 & $.742^{* *}$ \\
\hline & Sig. (2-tailed) & & .000 & .000 & .718 & .502 & .000 \\
\hline & $\mathrm{N}$ & 92 & 92 & 92 & 92 & 92 & 92 \\
\hline \multirow[t]{3}{*}{$\begin{array}{l}\text { entrepreneur } \\
\text { skill }\end{array}$} & $\begin{array}{l}\text { Pearson } \\
\text { Correlation }\end{array}$ & $.660^{* *}$ & 1 & $.733^{* *}$ & -.062 & -.032 & $.714^{* * *}$ \\
\hline & Sig. (2-tailed) & .000 & & .000 & .560 & .761 & .000 \\
\hline & $\mathrm{N}$ & 92 & 92 & 92 & 92 & 92 & 92 \\
\hline \multirow[t]{3}{*}{ Interest rate } & $\begin{array}{l}\text { Pearson } \\
\text { Correlation }\end{array}$ & $.660^{* *}$ & $.733^{* *}$ & 1 & -.074 & -.072 & $.689^{* *}$ \\
\hline & Sig. (2-tailed) & .000 & .000 & & .484 & .496 & .000 \\
\hline & $\mathrm{N}$ & 92 & 92 & 92 & 92 & 92 & 92 \\
\hline \multirow[t]{3}{*}{ Saving } & $\begin{array}{l}\text { Pearson } \\
\text { Correlation } \\
\end{array}$ & -.038 & -.062 & -.074 & 1 & $.640^{* *}$ & $.457^{* *}$ \\
\hline & Sig. (2-tailed) & .718 & .560 & .484 & & .000 & .000 \\
\hline & $\mathrm{N}$ & 92 & 92 & 92 & 92 & 92 & 92 \\
\hline \multirow[t]{3}{*}{ Loan } & $\begin{array}{l}\text { Pearson } \\
\text { Correlation }\end{array}$ & .071 & -.032 & -.072 & $.640^{* *}$ & 1 & $.537^{* *}$ \\
\hline & Sig. (2-tailed) & .502 & .761 & .496 & .000 & & .000 \\
\hline & $\mathrm{N}$ & 92 & 92 & 92 & 92 & 92 & 92 \\
\hline \multirow[t]{3}{*}{ WE } & $\begin{array}{l}\text { Pearson } \\
\text { Correlation }\end{array}$ & $.742^{* *}$ & $.714^{* *}$ & $.689^{* *}$ & $.457^{* *}$ & $.537^{* *}$ & 1 \\
\hline & Sig. (2-tailed) & .000 & .000 & .000 & .000 & .000 & \\
\hline & $\mathrm{N}$ & 92 & 92 & 92 & 92 & 92 & 92 \\
\hline
\end{tabular}

\section{Copyright Disclaimer}

Copyright for this article is retained by the author(s), with first publication rights granted to the journal.

This is an open-access article distributed under the terms and conditions of the Creative Commons Attribution license (http://creativecommons.org/licenses/by/3.0/). 